\title{
Aging and the lacrimal system
}

\author{
N J van Haeringen
}

The lacrimal system consists of the lacrimal glands, the tear film in contact with the conjunctiva and cornea, and the lacrimal drainage system through the nasolacrimal duct to the nose. In this review the age related changes in this system will be given, including tear chemistry of the tear film. Certain aspects of tear physiology change with age, such as reflex secretion by the lacrimal gland, tear volume, and tear film stability, whereas others remain more or less unchanged, such as basal tear production.

The reflex secretion of tears, as measured by Schirmer's I method (without anaesthesia), decreases significantly with increasing age as already was observed by Schirmer ${ }^{1}$ in 1903 and by many others thereafter. ${ }^{2-20}$ The age groups investigated mostly cover the $20-80$ age range and the reduction in Schirmer values from the youngest to the oldest age group is about $70 \%$. In contrast with these findings $\mathrm{Xu}$ and $\mathrm{Tsubota}^{21}$ and Nava et $\mathrm{al}^{22}$ failed to demonstrate the decline of the Schirmer I value with age although in both studies the numbers of subjects were large. This discrepancy is probably attributable to the acknowledged variability in the performance of the Schirmer test - that is, in the latter studies the patients were asked to blink normally after placing the Schirmer strip. It is conceivable that blinking causes an extra irritation, which in elderly people may increase reflex tearing compared with a closed eye condition, such as is employed mostly. Newborn babies secrete tears in the first 24 hours of life. ${ }^{23}$ Premature infants may fail to secrete tears at birth, depending on the degree of prematurity. ${ }^{24}$ A negligible number of tears are formed during sleep, ${ }^{12526}$ in the course of which the protein pattern is also altered dramatically. ${ }^{27}$ The basal tear production, as measured by fluorophotometry from the decay of fluorescence after instillation of fluorescein solution in the eye, was found to decrease with age, ${ }^{28}{ }^{29}$ to increase, ${ }^{26}$ or to show no significant correlation ${ }^{20}{ }^{30-33}$ in the age range between 10 and 90 years. The volume of tears present on the surface of the eye declines with increasing age. ${ }^{20} 2934$ Wide discrepancies in the absolute values of tear flow and tear volume were found, although the investigators used the same method of fluorescein dilution. Probably the difficulty in avoiding stimulation during testing is the primary reason. Therefore, a standardised protocol for the measurement of tear turnover by fluorophotometry has been drawn up in cooperation with experts in different countries of the European Union. ${ }^{31}$ Disappearance of fluorescein from the tear film after application of fluorescein in an eyedrop was found to be slower in the age group of 20-30 years compared with a group of 50-65 year olds, ${ }^{35}$ which was ascribed to slower drainage and tear production in the older age group resulting in longer corneal contact time of the eyedrop. The increase in corneal penetration of fluorescein with advancing age ${ }^{36} 37$ seems to be the result of a greater corneal contact time rather than a rise in epithelial permeability.

The lacrimal transit time through the nasolacrimal duct, measured with a modified Jones test by the time of appearance of fluorescein on a cotton applicator in the nose, slows with age ${ }^{38}$ Also a decreased lacrimal drainage capacity was found with increasing age when measured by the drop test. ${ }^{33}$ In the drop test the disappearance of fluorescein is measured after repeated instillation of drops of $10 \mu \mathrm{l}$ of lukewarm saline solution into the conjunctival sac over 3 minutes. The volume of saline solution drained by the lacrimal passage can thus be calculated.

The tear evaporation rate has not been found to be correlated with age. ${ }^{39}{ }^{40}$ The evaporation is primarily controlled by the lipid layer of the tear film and lipid layer thickness appears to be constant for different age groups. ${ }^{41}$

The tear film stability, as measured in seconds by the tear break up time (BUT, the time needed after blinking of the fluorescein treated eye for the appearance of dark spots in the fluorescence of the tear film) is independent of the patient's age according to Norn ${ }^{42}$ and Lemp and Hamil, ${ }^{43}$ who introduced this method for clinical use. More recent studies report an increase with age in the number of BUT values of less than 10 seconds. ${ }^{44-46}$

Various morphological changes increasing with age were observed in the lacrimal gland, especially periductal fibrosis, which is speculated to be related to the decrease in tear outflow with age and interlobal ductal dilatation, which may be caused by stenosis of the excretory duct in the fornix of the conjunctiva. ${ }^{47}$ Magnetic resonance imaging showed sex related influences on the lacrimal gland structure during aging. The thickness and area of the lacrimal gland decreased with age in women, but not in men. Furthermore, the signal intensity of magnetic resonance increased with age only in women. ${ }^{48}$ The goblet cells of the conjunctival epithelium produce the mucous component of the tears, which enables tears to stick to the corneal surface. Reports on goblet cell counts in the conjunctiva in relation to age show discrepancies. Abnormal goblet cells, containing a high proportion of neutral rather than acidic mucopolysaccharides, and occlusion of goblet cells with retention of their contents were reported to increase with age. ${ }^{49}$ Reduction in the goblet cell population was observed in subjects over 60 years of age $\mathrm{e}^{50}$ and in another study in those over 80 years. ${ }^{51}$ In the latter this was sometimes associated with the presence of 'hyaline bodies', which are periodic acid Schiff positive and possibly represent a degenerative form of goblet cells. In a more recent study, using conjunctival impression cytology, in 73 healthy volunteers no correlation between age and goblet cell count could be demonstrated ${ }^{46}$; also by studying peroperative conjunctival biopsies from 54 patients with primary open angle glaucoma undergoing filtering surgery, no statistically significant difference was observed across three age groups between 40 and over 75 years. ${ }^{52}$

Normally the decreased reflex tear secretion capacity in the older eye may be compensated by a reduced lacrimal drainage. ${ }^{40}$ The condition of 'dry eye' with subjective symptoms including burning, itching, sticking, dryness, mucus discharge, and foreign body sensation, occurring with increasing frequency in older patients may be caused by an imbalance due to abnormal low tear production or a 
high evaporation rate. The lids may become less taut with age and this interferes with normal blinking function, causing a higher evaporation because the tear film is not properly restored over the ocular surface. In some cases the 'dry eye' is associated with defective mucus secretion or the presence of particulate matter in the tear film, which usually consists of mucus that is not remaining in solution because of moderately depleted tear flow. In other cases the tear production is still normal, and this defect in mucus secretion with its secondary irritation may lead to overproduction of the aqueous part of the tear film. This aggravates the condition and may confuse the clinical picture. $^{53}$

The composition of tears is rather complex and varies over a broad range of normal levels for the different components. ${ }^{54}$ Moreover, the method of tear collection may influence the composition. Stimulation of tear flow may result in lower values if the component under investigation is derived from the cornea or conjunctiva. Microtrauma caused by Schirmer test paper or cellulose sponges in the conjunctiva may increase leakage of plasma components and tissue cell content into the collected tears. Furthermore, diurnal variation in the concentration may contribute to variation in test results, such as has been described for lysozyme. ${ }^{55}$

Conflicting reports exist as to the effect of age on $\operatorname{IgA}$ levels, some reporting a slight decrease with age $e^{56}$ while others give a gradual increase $e^{57}$ or no difference. ${ }^{58}$ Tears collected with capillaries ${ }^{57}$ showed lower mean values of about $300 \mathrm{mg} / 1$ compared with the samples collected with filter paper ${ }^{56}$ and sponge, ${ }^{58}$ with mean values of about 600 $\mathrm{mg} / \mathrm{l}$. At birth no IgA is detected in children's tears but within 2 weeks it had risen to a level of $20 \mathrm{mg} / 1 .^{59}$ Adult values were found at about 4-8 years of age..$^{50}$ Fluorescent antibody staining of IgA in plasma cells in biopsies of accessory lacrimal glands of the conjunctiva showed no trend with age.$^{61}$ Some authors found organised mucosa associated lymphoid tissue (MALT) in the normal human conjunctiva, ${ }^{62-64}$ others found it only in $31 \%$ of cases and suggest that MALT is acquired during life in a proportion of apparently asymptomatic individuals. ${ }^{65}$

Under physiological conditions levels of albumin, IgG, and caeruloplasmin in tears of adults remain low and static until an apparent increase after the fifth decade. ${ }^{58}$ At birth IgG and albumin are about threefold higher than adult levels, probably reflecting a propensity for transudation from the plasma, but by 2-3 months they drop to near adult levels. ${ }^{59}$ Age increased leakage of conjunctival vessels ${ }^{66}$ and conjunctival hyperaemia ${ }^{67}$ might be held responsible for the elevated levels of these plasma derived proteins at older age. In pathological conditions local production of IgG by conjunctival tissues has been suggested. ${ }^{68} 69$

The lacrimal gland proteins lysozyme ${ }^{5670-73}$ and lactoferrin ${ }^{5674}$ decline linearly and progressively with age in adults with a reduction of about $35 \%$ over the range $20-80$ years. Lysozyme is not detected in children's tears at birth but within 2 weeks attains a level of $170 \mathrm{mg} / 1 .^{59}$ Adult values are found at about 4-8 years of age..$^{59} 60$

Osmolality in tears of normal eyes generally remains within the limits of $280-330 \mathrm{mOsm} / 1$ and reportedly is not significantly affected by age ${ }^{75-77}$ except in one study, ${ }^{20}$ where over an age range of 10-85 years a significant increase in osmolality was found.

A variety of medications for various conditions, mostly outside the field of ophthalmology, are known to be inhibitory to tear production. ${ }^{78}{ }^{79}$ These drugs comprise $\beta$ blockers, ganglion blockers, hypnotics, and sedatives such as phenobarbitone and benzodiazepines, neuroleptics such as phenothiazines, tranquillisers such as diazepam, and antidepressives such as dibenzazepines and monoamine oxidase inhibitors. Even aspirin exerts an inhibitory effect on the tear production ${ }^{80}$ and a change in the composition of tears. ${ }^{81}$ Therefore it is conceivable that in control people, considered to be normal or healthy, a diminished tear production is measured which is caused by these drugs. Moreover, if the consumption of these drugs is related to age then it is possible that in some studies the changes observed in several variables of lacrimal gland function are drug induced rather than age related.

N J VAN HAERINGEN

The Netherlands Ophthalmic Research Institute,

PO Box 12141, 1100 AC Amsterdam, Netherlands

1 Schirmer O. Studiën zur Physiologie und Pathologie der Tränenabsonderung und Tränenabfuhr. Graefes Arch Ophthalmol 1903;56:197-291.

2 Henderson JW, Prough WA. Influence of age and sex on flow of tears. Arch Ophthalmol 1950;43:224-31.

3 Mitzukawa T, Kamada K, Hama H. On the physiological standard of the Mitzukawa T, Kamada K, Hama H. On the
tear volume. Acta Med Shikoku 1951;2:307.

4 de Rotth A. Lacrimation in normal eyes. Arch Ophthalmol 1953;49:185-9.

5 Stiewe M. Altersabhängigkeit der Tränensekretion. Z Augenheilkd 1962;15: 318-23.

6 Wright JC, Meger GE. A review of the Schirmer test for tear production. Arch Ophthalmol 1962;67:564-5.

7 Zintz R, Schilling T. Ein kolorometrisches Verfahren zur Messung des Flüssigkeitsvolumens im Bindehautsack. Klin Monatsbl Augenheilkd 1964;144: 393-412.

8 van Bijsterveld OP. Diagnostic test in the sicca syndrome. Arch Ophthalmol 1969;82:10-4. 9 Zappia R, Milder B. Lacrimal drainage function. Am f Ophthalmol 1972;74:

10 Whaley $\mathrm{K}$, Williamson J, Wilson T, McGavin DDM, Hughes GRV, Schmulian LR, et al. Sjögren's syndrome and autoimmunity in a geriatric population. Age Aging 1972;1:197-205.

11 Gawdat I. Estimation of the amount of tears present in conjunctival cul-desac of normal non-trachomatous Egyptian eyes. Bull Ophthalmol Soc Egypt 1975;68:611-6.

12 Haberich FJ. Die Tränenflüssigkeit, ihre Zusammensetzung und ihre Bedeutung beim Tragen von Contactlinsen fur das Normalauge und bei Erkrankung. Contactlinse 1977;11:14-21.

13 Hornblass A, Ingis TM. Lacrimal function test. Arch Ophthalmol 1979;97:1654-5.

14 Koetting RA, Andrews CE. The relationship of age, keratometry, and miscellaneous physiological factors in hydrogel lens wear. Am f Optom Physiol Opt 1979;56:642-6.

15 Marquardt R, Wenz FH. Vergleichende Untersuchungen der Becherzellzahl in der menschlichen Bindehaut, der Tränenbasissekretion und Tränenfilmstabilität. Ber D Ophthalmol Ges 1980;77:441-5.

16 Rodney WM, Louie J, Puffer JC. Schirmer's test of lacrimation. Am Fam Physician 1981;24:161-4.

17 Arrata M, Sanit F, Lutcher B, Py D, Rougas C. Klinische Untersuchungen der normalen Tränensekretion. Contactologia 1982;4:215-9.

18 Scad RD, Ehrich W, Höh H. Schirmer's I-test and age-dependent normal limits. Contactolog 1987;9:86-90.

19 Puderbach S, Stolze HH. Tear ferning and other lacrimal tests in normal persons of different ages. Int Ophthalmol 1991;15:391-5.

20 Mathers WD, Lane JA, Zimmerman MB. Tear film changes associated with normal aging. Cornea 1996;15:229-34.

$21 \mathrm{Xu} \mathrm{K}$, Tsubota $\mathrm{K}$. Correlation of tear clearance rate and fluorophotometric assessment of tear turnover. Br f Ophthalmol 1995;79:1042-5.

22 Nava A, Barton K, Monroy DC, Pflugfelder SC. The effects of age, gender, and fluid dynamics on the concentration of tear film epidermal growth factor. Cornea 1997;16:430-8.

23 Apt L, Cullen BF. Newborns do secrete tears. FAMA 1964;189:951.

24 Patrick RK. Lacrimal secretion in full-term and premature babies. Trans Ophthalmol Soc UK 1974;94:283-5

25 Baum J. A relatively dry eye during sleep. Cornea 1990;9:1.

26 Jordan A, Baum J. Basic tear flow. Does it exist? Ophthalmology 1980;87:920-30.

27 Sack RA, Tan KO, Tan A. Diurnal tear cycle: evidence for a nocturnal inflammatory constitutive tear fluid. Invest Ophthalmol Vis Sci 1992;33: inflamm.

28 Furukawa RE, Polse KA. Changes in tear flow accompanying aging. Am $\mathcal{F}$ Optom Physiol Optics 1978;55:69-74.

29 Hirase K, Shimuzu A, Yokoi N, Nishida K, Kinoshita S. Age-related alteration of tear dynamics in normal volunteers. Acta Soc Ophthalmol fap 1994; 98:575-8.

30 Kuppens EVMJ, Stolwijk TR, de Keizer RJW, van Best JA. Basal tear turnover and topical timolol in glaucoma patients and healthy controls by fluorophotometry. Invest Ophthalmol Vis Sci 1992;33:3442-8.

31 van Best JA, Benitez del Castillo JM, Coulangeon LM. Measurement of basal tear turnover using a standardized protocol. European concerted action on ocular fluorometry. Graefes Arch Clin Exp Ophthalmol 1995;233: $1-7$

32 Puffer MJ, Neault RW, Brubaker RF. Basal precorneal tear turnover rate in the human eye. Am $\mathcal{F}$ Ophthalmol 1980;89:369-76.

33 Sahlin S, Chen E. Evaluation of the lacrimal drainage function by the drop test. Am f Ophthalmol 1996;122:701-8.

34 Hamano T, Mitsunaga S, Kotani S, Hamano T, Hamano K, Hamano H, et al. Tear volume in relation to contact lens wear and age. CLAO f 1990;16: 57-61.

35 Barendsen $\mathrm{H}$, Oosterhuis JA, van Haeringen NJ. Concentration of fluorescein in tear fluid after instillation as eye-drops. I. Isotonic eye-drops. Ophthalmic Res 1979;11:73-82.

36 Chang SW, Hu FR. Changes in corneal autofluorescence and corneal epithelial barrier function with aging. Cornea 1993;12:493-9. 
37 Nzekwe EU, Maurice DM. The effect of age on the penetration of fluorescein into the human eve. 7 Ocul Pharmacol 1994;10:521-3.

38 Hagele JE, Guzek JP, Shavlik GW. Lacrimal testing. Age as a factor in Jones testing. Ophthalmology 1994;101:612-7.

39 Rolando M, Refojo MF. Tear evaporimeter for measuring water evaporation rate from the tear film under controlled conditions in humans. Exp Eye Res 1983;36:25-32.

40 Tomlinson A, Giesbrecht C. Effect of age on human tear film evaporation in normals. Adv Exp Med Biol 1994;352:271-4

41 Norn MS. Semi-quantitative interference study of fatty layer of pre-corneal film. Acta Ophthalmol 1979;57:766-74.

42 Norn MS. Desiccation of the precorneal film. I. Corneal wetting time. Acta Ophthalmol 1969;47:865-80.

43 Lemp MA, Hamil JR. Factors affecting tear film break up in normal eyes. Arch Ophthalmol 1973;89:103-5.

44 Zhang HC. An investigation of vital staining of the ocular surface and BUT of the tear film in Chinese. Chin 7 Ophthalmol 1990;26:43-6.

45 Patel S, Farrell JC. Age-related changes in precorneal tear film stability. Optom Vis Sci 1989;66:175-8.

46 Paschides CA, Petroutsos G, Psilas K. Correlation of conjunctival impression cytology results with lacrimal function and age. Acta Ophthalmol impression cytolog

47 Obata H, Yamamoto S, Horiuchi H, Machinami R. Histopathologic study of human lacrimal gland. Statistical analysis with special reference to aging. Ophthalmology 1995;102:678-86.

48 Ueno H, Ariji E, Izumi M, Uetani M, Hayashi K, Nakamura T. MR imaging of the lacrimal gland. Age-related and gender-dependent changes in size and structure. Acta Radiol 1996;37:714-9.

49 Kessing SV. Mucous gland system of the conjunctiva. A quantitative normal anatomic study. Acta Ophthalmol 1968;Suppl 95.

50 Marquardt R. Histological studies of goblet cell counts in the human conjunctiva. In: Holly FJ, ed. The preocular tear film in health, disease, and contact lens wear. Lubbock, TX: Dry Eye Institute, 1986:312-7.

51 Abdel-Kahlek LMR, Williamson J, Lee WR. Morphological changes in the human conjunctival epithelium. I. In the normal elderly population. $\mathrm{Br} f$ Ophthalmol 1978;62:792-9.

52 Gwynn DR, Stewart WC, Hennis HL, McMillan TA, Pitts RA. The influence of age upon inflammatory cell counts and structure of conjunctiva in chronic open-angle glaucoma. Acta Ophthalmol 1993;71: conjunctiv.

53 Blodi FC. Eye problems of the elderly. Ophthalmologica 1980;181:121-8.

54 van Haeringen NJ. Clinical biochemistry of tears. Surv Ophthalmol 1981;26: $84-96$.

55 Horwitz BL, Christensen GR, Ritzmann SR. Diurnal profiles of tear lysozyme and gamma A globulin. Am f Ophthalmol 1978;10:75-80.

56 McGill JI, Liajos GM, Goulding N, Seal DV. Normal tear protein profiles and age-related changes. Br F Ophthalmol 1984;68:316-20.

57 Sen DK, Sarin GS, Mathur GP, Saha K. Biological variation of immunoglobulin concentrations in normal human tears related to age and sex. Acta Ophthalmol 1978;56:439-44.

58 Tchah H. Measurement of IgA level in normal human tears by enzyme-linked immunosorbent assay. Korean f Ophthalmol 1989;3:70-4.

59 Watson R, Wallis JO. Development with age of IgA, IgG, albumin, lysozyme, and total protein in children's tears. Fed Proc 1975;34:1032.
60 van Agtmaal EJ. Vitamin A and proteins in tear fluid. A nutritional field survey on preschool children in northeast Thailand. Thesis. University of 1989

61 Allansmith MR, Kajiyama G, Abelson MB, Simon MA. Plasma cell content of main and accessory lacrimal glands and conjunctiva. Am $\mathcal{F}$ Ophthalmol $1976 ; 82: 819-26$.

62 Chandler JW, Gilette TE. Immunologic defence mechanisms of the ocular surface. Ophthalmology 1983;90:585-91.

63 Jakobiec FA, Lefkowitch J, Knowles DM. B- and T-lymphocytes in ocular disease. Ophthalmology 1984;91:635-54.

64 Knop E, Knop N. The mucosa associated lymphoid tissue of the human conjunctiva consists of three components: solitary follicles, crypt associated MALT and a lymphoid layer. Invest Ophthalmol Vis Sci 1997;38:S125.

65 Wotherspoon AC, Harman-Lea S, Isaacson PG. Mucosa-associated lymphoid tissue (MALT) in the human conjunctiva. F Pathol 1994;174:337.

66 Takahashi A, Okisaka S, Akeo K, Taketani P. Aging changes in conjunctiva visualized by fluorescein angiography and histopathology. Acta Soc .

67 McMonnies CW, Ho A. Conjunctival hyperaemia in non-contact lens wearers. Acta Ophthalmol 1991;69:799-801.

68 Ballow M, Mendelson L, Donshik P, Rooklin A, Rapacz P. Pollen-specific IgG antibodies in the tears of patients with allergic-like conjunctivitis. $\mathcal{F}$ Allergy Clin Immunol 1984:73:376-81.

69 Lundh RL, Liotet S, Pouliquen Y. Study of the human blood-tear barrier and the biochemical changes in the tears of 30 contact lens wearers $(50$ eyes). Ophthalmologica 1984;188:100-5.

70 Mackie IA, Seal DV. The questionable drye eye. Br F Ophthalmol 1981;65:2-9.

71 Bonavida B, Sapse AT. Human tear lysozyme. II. Quantitative determination with standard Schirmer strips. Am $\mathcal{F}$ Ophthalmol 1968;66:70-5.

72 Sen DK, Sarin GS. Immunoassay of human tear lysozyme. Am f Ophthalmol 1980;90:715-8.

73 Pietsch RL, Pearlman ME. Human tear lysozyme variables. Arch Ophthalmol 1973;90:94-6.

74 Lee M, Horimoto K, Hamano T, Negoro K, Takamura E, Danjo Y, et al. Lactoferrin content in the tear fluid in normal eyes. Fap $\mathcal{F}$ Clin Ophthalmol 1993;47:541-4.

75 Farris RL, Stuchell RN, Mandel ID. Basal and reflex human tear analysis. I. Physical measurements: osmolarity, basal volumes, and reflex flow rate. Ophthalmology 1981;88:852-7.

76 Craig JP, Tomlinson A. Effect of age on tear osmolality. Optom Vis Sci 1995; 72:713-7.

77 Gilbart JP, Farris RL, Santamaria J. Osmolarity of tear microvolumes in keratoconjunctivitis sicca. Arch Ophthalmol 1978;96:677-81.

78 van Haeringen NJ, Bleeker GM. Lider und Tranenapparat. In: Hockwin O, Koch H-R, eds Arzneimittelnebenwirkungen am Auge. Stuttgart: G Fischer, 1982:11-4.

79 Crandall DC, Leopold IH. The influence of systemic drugs on tear constituents. Ophthalmology 1979;86:115-25

80 Carreras y Matas M. Mogadon, aspirina y secrecion lagrimal. Rev Esp OtoNeuro-Oftalmol 1973;31:245-6.

81 van Haeringen NJ, Glasius E. Lysosomal hydrolases in tears and the lacrimal gland; effect of acetylsalicylic acid on the release from the lacrimal gland. Invest Ophthalmol Vis Sci 1980;19:826-9. 